Галаган В. І., канд. військ. наук, доцент

(0000-0001-9578-0895);

Полішко С. В. канд. техн. наук, ст. наук. співроб. (0000-0002-2172-7618);

Бондарчук С. В.

(0000-0003-0624-9782);

Фатальчук А. В.

(0000-0001-8944-4051)

Центр воєнно-стратегічних досліджень Національного університету оборони України імені Івана Черняховського, Київ

\title{
Пропозиції щодо формування вимог під час розроблення (вдосконалення) інформаційних систем військового призначення Збройних Сил України
}

Резюме. У статті проведено аналіз порядку і методів формування вимог під час розроблення (вдосконалення) інформаційних систем військового призначення Збройних Сил України та надано пропозиції щодо їх застосування.

Ключові слова: розроблення інформаційних систем, формування вимог, система військового призначення.

Постановка проблеми. У рамках Плану дій щодо впровадження оборонної реформи у Міністерстві оборони та Збройних Силах України у 2019-2020 роках та Концепції інформатизації Міністерства оборони України заплановане створення єдиної інформаційної системи управління оборонними ресурсами (DRMIS), яка включатиме інформаційні системи управління інфраструктурою, особовим складом, видами забезпечення та ін.

Розроблення нових i вдосконалення наявних інформаційних систем потребує виконання визначеного алгоритму заходів, які призведуть до їх впровадження у постійну експлуатацію (прийняття на озброєння).

Одним 3 найвагоміших під час розроблення (вдосконалення) інформаційних систем $є$ етап формування вимог. Необхідність визначення вимог до інформаційної системи виникає у випадках: розроблення нової інформаційної системи; під час уточнення (деталізації) потреб замовника у процесі розроблення або налаштування інформаційної системи; за необхідності внесення змін до інформаційної системи під час її експлуатації.

Щоразу перед фахівцями замовника i розробника інформаційної системи постає завдання формування вимог, вибір рівня їх деталізації та методів опису.

Досвід створення і впровадження інформаційних систем показує, що будь-які спрощення та недоліки, допущені під час формування вимог і їх деталізації, виборі методів їх визначення, може призвести до значних часових затримок 3 реалізації проєктів або повної їх зупинки [1].
Аналіз останніх досліджень та публікацій. На сьогодні в більшості фахових публікацій [3-5] 3 питань розроблення (вдосконалення) інформаційних систем немає чіткого розуміння щодо порядку та методів, які використовуються під час формування вимог.

Кожен 3 авторів пропонує використовувати свої підходи та методи формування вимог до інформаційних систем, які здебільшого направлені на бізнес-сектор, не надаючи до того ж рекомендацій для державних структур. Також у цих публікаціях не наведена специфіка використання методів формування вимог під час розроблення інформаційних систем військового призначення, які мають характерні особливості та характеристики.

Нині замовниками (посадовими особами Міністерства оборони України та Генерального штабу Збройних Сил України) та розробниками інформаційних систем військового призначення використовуються застарілі нормативні документи (ГОСТ 34.601-90 "Комплекс стандартов на автоматизированные системы. Автоматизированные системы. Стадии создания") [2], у яких надається тільки поверхнева послідовність щодо формування вимог до автоматизованої системи, проте не вказуються методи, які необхідно використовувати. Водночас, новітні нормативні документи та регламенти щодо створення інформаційних систем знаходяться в стадії розроблення та впровадження.

3 огляду на викладене, метою статті $\epsilon$ проведення аналізу порядку та методів 
формування вимог під час розроблення (вдосконалення) інформаційних систем військового призначення Збройних Сил України та надання пропозицій щодо їх застосування.

Виклад основного матеріалу. Розроблення будь-якої інформаційної системи відбувається відповідно до закономірностей життєвого циклу проєкту, фазами якого є: формування концепції; розроблення; реалізація; завершення. Розрізняють дві основні формальні моделі життєвого циклу проєктування інформаційних систем: каскадну (послідовну) i спіральну (ітераційну). Відповідно до каскадної моделі перехід на наступний етап може відбуватися тільки після завершення попереднього. Спіральна модель передбачає циклічне виконання всіх етапів каскадної моделі, унаслідок чого реалізація технічних рішень перевіряється за допомогою прототипів. Кожен виток спіралі відповідає створенню фрагмента або версії програмного забезпечення, на ньому уточнюються цілі та характеристики проєкту, визначається його якість і плануються подальші роботи.

Для збройних сил доцільнішим варіантом розроблення інформаційних систем $\epsilon$ каскадна модель (особливо, що стосується бойових систем). Спіральна модель проєктування може застосовуватися для великих розгалужених інформаційних систем, які можуть включати декілька незалежних підсистем, кожна 3 яких виконує окреме цільове призначення (наприклад - логістичні системи). До того ж, основний недолік спіральної моделі міститься в тому, що немає можливості повноцінного застосування (тестування) інформаційної системи, яка має неповну функціональність.

Для будь-якої моделі життєвого циклу проєктування інформаційних систем формування вимог $\epsilon$ обов'язковим та відповідальним процесом.

Формування вимог - процес, що включає заходи, необхідні для створення $\mathrm{i}$ затвердження документа, який містить специфікацію системних вимог.

Розрізняють чотири основні етапи процесу формування вимог:

аналіз можливості створення системи; формування і аналіз вимог; специфікація вимог i створення відповідної документації; атестація вимог.

Аналіз можливості здійснення проєкту інформаційної системи військового призначення має містити відповіді на такі питання:

відповідність системи, яку планується розробляти, загальним i частковим цілям замовника і розробника;

можливості реалізації інформаційної системи, яку планується розробляти, 3 використанням передових світових технологій, що $€$ на сьогодні, та заданої вартості;

можливість об'єднання системи, яку планується розробляти, 3 іншими системами військового призначення, які вже експлуатуються.

Проведення аналізу виконання проєкту включає збір та аналіз інформації про майбутню систему, написання відповідного звіту. До того ж розглядаються такі питання:

наслідки (у сфері оборони держави), якщо система не буде введена в експлуатацію; поточні проблеми, які існують в структурі (організаціі), і як система, яку планується розробляти, допоможе їх розв'язати;

яким чином система, яку планується розробляти сприятиме цілям і завданням структури (організаціі);

чи потребує розроблення системи технологій, які до цього не використовувалася в структурі (організаціï).

Після обробки зібраної інформації готується звіт за результатами проведеного аналізу про можливість створення інформаційної системи військового призначення.

На етапі формування $i$ аналізу вимог команда розробників працює 3 представниками замовника i кінцевими користувачами інформаційної системи для 3'ясування напряму застосування, опису системних сервісів, визначення режимів роботи системи та іiї характеристик, апаратних обмежень тощо.

Процес формування і аналізу вимог для інформаційних систем військового призначення має проходити низку етапів:

аналіз предметної області, під час якого спеціалісти-аналітики вивчають предметну область інформатизації, де використовуватиметься та експлуатуватиметься система;

збір вимог від представників замовника та користувачів - процес взаємодії 3 посадовими особами (представниками) замовника, що формують вимоги: під час цього процесу триває аналіз предметної області; 
класифікація вимог - на цьому етапі окремі (визначені) вимоги перетворюються (формуються) в логічно пов'язані групи вимог;

призначення пріоритетів - визначаються найважливіші вимоги.

Специифікація вимог - процес документування вимог в структурованому, доступному кожному учаснику робочої групи 3 розроблення інформаційної системи форматі. Специфікація вимог (Software Requirements Specification - $\quad S R S)$ використовується для поточного супроводження проєкту та подання вимог, які були сформовані. Специфікація вимог дає змогу визначити предметну область інформаційної системи відповідно до основних складових: даних, процесу i поведінки та застосовується для проведення приймальних випробувань.

Атестація вимог - процес перевірки вимог на достовірність, несуперечливість, повноту i можливість їх забезпечення. Атестація повинна продемонструвати, що вимоги дійсно визначають таку інформаційну систему, яку хоче мати замовник. Крім того, атестація виявляє помилки в специфікації вимог, які можуть призвести до перероблення інформаційної системи і значних фінансових витрат, якщо ці помилки будуть виявлені під час таких етапів розроблення або введення іiї в експлуатацію.

Для формування вимог у світовій практиці найчастіше використовуються підходи, що базуються на:

методі опорних точок зору;

методі сценаріїв;

етнографічному методі.

Зрозуміло, що під час розроблення (вдосконалення) інформаційних систем для потреб Збройних Сил України не може існувати універсального підходу для аналізу та формування вимог. За досвідом роботи, як правило, для розроблення великих інформаційних систем, зокрема і військового призначення, використовується декілька методів одночасно.

Метод опорних точок зору. Будь-яка інформаційна система, яка підлягає розробленню, надалі матиме кінцевих користувачів, які знаходяться на різних рівнях ієрархічної структури та мають виконувати завдання за своїми функціональними обов'язками. Багато посадових осіб, які беруть участь у формуванні вимог, у своїх вимогах до системи висловлюють власні інтереси та зацікавленості. Отже, у процесі формування вимог для інформаційних систем військового призначення мають бути задіяні посадові особи починаючи від тактичної ланки до вищого керівного складу МО України та ГШ 3С України, розробники програмного забезпечення та персонал, що здійснюватиме його супроводження i подальшу модернізацію, адміністратори баз даних, зв’язківці та інші.

Значна кількість особового складу, який залучається для формування вимог показує, що навіть для відносно простої інформаційної системи існує значна кількість різних точок зору, які мають бути розглянуті. Різні точки зору на проблему дають змогу побачити іï 3 різних сторін.

Цей підхід надає можливість структуризації вимог і грунтується на тому, що отримані різні (опорні) точки зору використовуються за основу побудови та організації як процесу формування вимог, так i безпосередньо самих вимог. Сильна сторона методу, орієнтованого на різні опорні точки зору, в тому, що він визнає множину поглядів i забезпечує основу для виявлення суперечностей у вимогах, запропонованих різними посадовими особами.

У світовій практиці цей метод має назву - VORD (Viewpoint-Oriented Requirements Definition) - визначення вимог на основі точок зору). Основними етапами методу VORD є:

виявлення та ідентифікація опорних точок зору;

структурування точок зору;

документування опорних точок зору;

відображення системи точок зору.

Виявлення та ідентифікація опорних точок зору. Для виявлення та ідентифікації точок зору, як правило, використовується метод "мозкового штурму", за допомогою якого визначаються зовнішні, по відношенню до системи і взаємодіючі 3 нею, сутності та можливі системні сервіси. За допомогою цього методу вирішуються такі завдання: ідентифікація потенційних опорних точок зору; ідентифікація системних сервісів; визначення вхідних системних даних; визначення функціональних вимог; виявлення керуючих подій i виняткових ситуацій. До того ж враховуються і системні обмеження, які визначають, наскільки система обмежена під час іiі функціонування та обслуговування. Системні обмеження пов'язані 3 такими видами вимог: вимоги до інтерфейсу; до продуктивності; до безпеки; експлуатаційні вимоги; юридичні вимоги. 
Структурування точок зору створення ієрархії згрупованих точок зору. Загальносистемні сервіси надаються більш високим рівням ієрархії і успадковуються точками зору нижчого рівня. Той самий сервіс може бути пов'язаний з різними точками зору (якщо сервіс не пов'язаний 3 жодною точкою зору, то це означає, що виявлені не всі точки зору). Точки зору визначають вхідні дані і управляючу інформацію для сервісів.

Інформація, що отримана під час розгляду точок зору і сервісів, служить для структуризації їх в ієрархію наслідування. Ієрархія визначає, які підмножини точок зору успадковують сервіси i управляючу інформацію.

Документування опорних точок зору полягає в точному описі ідентифікованих точок зору і сервісів. До того ж, проводиться деталізація інформації про сервіси, їх вхідних, вихідних і управляючих даних. Ця інформація виявляється у посадових осіб, які формують вимоги, пов'язані 3 кожної опорною точкою зору. Для цього використовуються опис точок зору і опис сервісів у вигляді сценаріїв подій. На основі цього опису заповнюються шаблони точок зору і шаблони опису сервісів.

Відображення системи точок зору показує об'єкти, визначені на основі інформації, які містяться в опорних точках зору та здійснюється у графічному вигляді (діаграма ієрархії точок зору, сценарії подій).

Цей метод є більш універсальним та досить широко використовується під час розроблення інформаційних систем. Універсальність методу дає змогу активно використовувати його в розробленні інформаційних систем військового призначення, що було підтверджено під час розроблення підсистеми управління нерухомим військовим майном "Майно" та підсистеми управління процесом забезпечення житлом військовослужбовців “Житло” Єдиної системи управління адміністративногосподарськими процесами Збройних Сил України, які вже знаходяться у постійній (промисловій) експлуатації Збройних Сил України.

Метод сценаріїв. Як правило, людина простіше відтворює приклади 3 реального життя, ніж абстрактні описи. Розробники та замовники можуть використовувати інформацію, отриману з обстеження сценаріїв взаємодії із системою, для подальшого формування вимог.

Під "сценарієм" розуміється певна послідовність кроків, які описують дії керівника (користувача) i реакцію інформаційної системи на них.

Сутність методу сценаріїв полягає у прогнозуванні поведінки та стану інформаційної системи залежно від умов іiі використання та узгоджених, логічно взаємопов'язаних подій та послідовних кроків керівника (користувача).

Для реалізації цього методу розробляються сценарії подій, які використовуються для документування поведінки інформаційної системи, що представлені певними умовами та подіями. Загалом сценарії включають опис потоків даних, системних операцій i виняткових ситуацій, які можуть виникнути.

Розроблення сценарію починається із загального опису стану інформаційної системи, потім поступово деталізується за рівнями для створення повного опису взаємодії користувача із системою.

Світовий досвід показує, що найбільш часто і ефективно для розроблення сценаріїв використовується $\boldsymbol{U} \boldsymbol{M L}$ - уніфікована мова моделювання (Unified Modeling Language), яка може бути застосована для об'єктноорієнтованого аналізу та проектування інформаційних систем. Для розроблення сценаріїв використовується модуль use-case (сценарій використання, варіант використання, прецедент використання).

Як правило, модуль use-case описує сценарій взаємодії учасників (користувачів і системи). Учасників може бути два $i$ більше. Користувачем може виступати як посадова особа, так і інша система. Загалом сценарій використання фіксує угоду між учасниками системи про іiі поведінку та стан. Сценарій використання описує поведінку системи під час іiі відповідей на запит одного 3 користувачів, у різних умовах [5].

Усі основні види діяльності, такі як аналіз, проєктування, тестування, виконуються на основі використання різних сценаріїв. Під час аналізу та проєктування різноманітні варіанти дають змогу зрозуміти, як отримані результати змінюють архітектуру інформаційної системи і як вести себе компонентам системи, щоб реалізувати необхідну для користувача функціональність.

Стратегія сценаріїв використання під час формування вимог визначає необхідність додатково до запитання "чого користувачі чекають від системи?” також відповісти на запитання "що система має зробити для конкретного користувача?”. Такий підхід дає змогу шукати функції, які потрібні багатьом 
користувачам і виключати можливості, які не можуть допомогти виконувати свої повсякденні завдання.

Цей метод особливо корисний для деталізації вже сформульованих вимог, оскільки описує алгоритм виконання завдань користувачем та його взаємодію із системою. Кожен сценарій описує одне або кілька можливих взаємодій.

Метод сценаріїв буде найбільш актуальним для розроблення та аналізу інтерактивних інформаційних систем військового призначення, які, як правило, досить широко використовуються у збройних силах передових країн світу. Прикладом такої інформаційної системи для Збройних Сил України може бути захищена інформаційнааналітична система управління персоналом "Персонал" (прийнята на озброєння) та система управління особовим складом інформаційної системи управління оборонними ресурсами (DRMIS) (в стадії розроблення).

Етнографічний метод. Це метод проведення досліджень, що базується на процесі спостереження та унікальний тим, що поєднує цілий комплекс інструментарію: формулювання проблеми, вибір об'єкта дослідження, спостереження, збір та аналіз результатів, обробка результатів дослідження, формулювання висновків.

Сутність етнографічного методу в процесі формування вимог полягатиме в тому, що учасники робочої групи, які виконують формування вимог мають знаходитися в "робочому" середовищі (організації, структурі, підрозділі), де використовуватиметься інформаційна система та здійснювати нагляд i протоколювання реальних дій (які планується автоматизувати), що виконуються керівним складом i користувачами. Значення етнографічного підходу полягає у допомозі виявляти неявні вимоги до інформаційної системи, які відображають реальні аспекти іï розроблення та експлуатації.

Необхідність використання цього методу виникає у зв'язку 3 тим, що представникам розробника та замовника важко чітко описати всі аспекти завдань та роботи що виконується, оскільки спосіб ii виконання часто визначається їх характером i практичним досвідом. Кожна посадова особа розуміє свої завдання, проте, як правило, не може пояснити іiі взаємозв'язок 3 іншими видами робіт, які виконуються в структурі (організаціi).
Соціальні та організаційні чинники, які впливають на роботу, однак не є очевидними, можуть стати явними, якщо описані неупередженими спостерігачами. Тобто, потрібно для кожного елементу інформаційної системи (АРМ, користувачі, обладнання, програмне забезпечення) визначити такі комфортні сервіси, які дають змогу найбільш ефективно розробити та використати систему загалом.

Досвід розроблення та вдосконалення інформаційних систем показує, що для отримання ефективнішого результату етнографічний метод формування вимог можна об'єднати з прототипуванням - процес створення прототипу програми - макета (чорнового, пробної версії) системи для перевірки придатності запропонованих для застосування концепцій, архітектурних (технологічних) рішень, а також для представлення програми замовнику на ранніх стадіях процесу розроблення. Етнографічний метод дає змогу отримати вимоги, які враховуються в прототипі, який розробляється. Крім того, етнографічний метод використовується під час розв'язання конкретних проблем прототипуванням та оцінюванні створеного прототипу.

Найбільш широко цей метод застосовувався під час розроблення підсистеми управління нерухомим військовим майном "Майно" та підсистеми управління процесом забезпечення житлом військовослужбовців “Житло” Єдиної системи управління адміністративно-господарськими процесами Збройних Сил України. Робоча група, яка складалася 3 представників компанії-розробника та осіб, які здійснювали супроводження проекту протягом тривалого часу працювала у підрозділах квартирноексплуатаційного забезпечення Збройних Сил України для детальнішого ознайомлення 3 бізнес-процесами та вимогами кінцевих користувачів.

Проте у використанні цього методу $є$ певні особливості. Етнографічний метод дає змогу деталізувати вимоги для інформаційних систем, чого не завжди можна досягти іншими методами розроблення вимог. Однак, оскільки цей метод орієнтований на кінцевого користувача, він не може охопити всі вимоги предметної області (військового напряму) та вимоги організаційного характеру. Отже він не $\epsilon$ всеохоплюючим підходом у формуванні вимог i має використовуватися спільно 3 іншими підходами, наприклад 3 методом сценаріїв. 
Зважаючи на викладене, етнографічний метод доцільно використовувати під час розроблення (вдосконалення) інформаційних систем, які мають складний та розгалужений алгоритм обробки даних. До таких інформаційних систем, насамперед, можна віднести логістичні системи, які є складними організаційно завершеними системами та складаються 3 низки підсистем (закупка, склади, запаси, транспорт, розподіл та ін.), взаємопов'язаних в єдиному процесі управління матеріальними потоками.

Отже, у процесі формування вимог під час розроблення (вдосконалення) інформаційної системи військового призначення може використовуватися один метод або оптимальне поєднання кількох методів. Вибір методів формування вимог залежатиме насамперед від складності та архітектури інформаційної системи (у разі удосконалення - від складності доопрацювань), підготовленості, професійного рівня, досвіду (за напрямом інформаційних технологій) замовника, кінцевих користувачів, розробника та часових термінів, які виділені для розроблення (удосконалення) інформаційної системи.

На сьогодні в організаційно-штатній структурі Збройних Сил України не передбачено посад фахівців, які повною мірою можуть успішно співпрацювати 3 ITкомпаніями щодо розроблення та вдосконалення інформаційних систем військового призначення. Як правило, для виконання завдань взаємодії з розробниками виділяються найбільш підготовлені 3 фахового напряму посадові особи, які добре знають бізнес-процеси у структурі (організації, підрозділі). Водночас ці посадові особи не мають відповідної освіти та досвіду роботи в інформаційному середовищі. Отже доцільно було б проводити підготовку посадових осіб, які плануються до участі у складі робочих груп щодо створення (вдосконалення) інформаційних систем військового призначення, на курсах (навчальних семінарах). Це навчання може проводитися як на базі профільних закладів (установ) Збройних Сил України, так і на базі компанійрозробників, що залучаються до розроблення (вдосконалення) інформаційних систем.

Висновки. Отже, проведений аналіз показує, що в кожному окремому випадку формування вимог до інформаційної системи військового призначення, яка використовуватиметься в діяльності структур (організацій) Збройних Сил України необхідне проведення обов'язкового пошуку підготовленими посадовими особами робочих груп (замовника та розробника) індивідуальних підходів і методів, що дасть змогу надалі розв'язати проблемні питання щодо розроблення (вдосконалення) та впровадження таких систем.

Подальші дослідження за цією тематикою доцільно зосередити на питаннях 3 розроблення нормативно-правової бази щодо впровадження нових інформаційних систем.

\section{СПИСОК ВИКОРИСТАНОЇ ЛІТЕРАТУРИ}

1. Морозов А. О., Кузьменко Г. Э., Яровий А. Д. Основні проблеми інформатизації Збройних Сил України на сучасному етапі. Наука і оборона. Київ, 2004. № 3. C. 16-22.

2. Информационная технология. Комплекс стандартов на автоматизированные системы. Автоматизированные системы. Стадии создания ГОСТ 34.601-90. URL: http://vsegost.com/Catalog/ 10/10698.shtml (дата звернення: 15.12.2019).

3. Вигерс Карл. Разработка требований к программному обеспечению : пер. с англ. Москва : Русская Редакция, 2004. 576 с.

4. Леффингуелл Д., Уидриг Д. Принципы работы с требованиями к программному обеспечению. Москва : Вильямс, 2002.

5. Мацяшек Л. Анализ требований и проектирование систем. Разработка информационных требований. Диалектика-

Вильямс.

Стаття надійшла до редакційної колегії 17.12.2019

\section{Proposals for forming requirements during the Development (Improvement) of Military Information Systems of the Armed Forces of Ukraine}

\section{Annotation}

One of the most important stages during the development (improvement) of Information Systems is the formation of its requirements. The need to define requirements arises in cases: new Information System development; in case of clarifying the needs of the customer in the process of developing the Information System or setting it up or if it is necessary to make changes to the Information System during its operation. 
Experience in the creation and implementation of Information Systems shows that any simplifications and shortcomings allowed in the formulation of requirements and their detailing can lead to significant delays during the implementation or complete stop.

The purpose of the article is to analyze the order and methods of requirements formation during the development (improvement) of the Military Information Systems and make proposals for their application.

Generally, requirements formation is a process that includes the steps which are required for the creation and approval of the documents containing the system requirements specification. The main stages of the requirements formation process are analysis of the possibility of creating a system; formation and analysis of requirements; specification of requirements; creation of relevant documentation; certification of requirements.

In formulating requirements during the development (improvement) of a military information system, one method or the optimal combination of several of them can be used. The choice of requirements formation methods depends on the complexity and architecture of the Information System (in case of improvement - on the complexity of refinements). The readiness, professional level, the experience of the customer, end-users and developers are important, as well as the periods allocated for the development (improvement) of the Information System.

Keywords: Information Systems development, requirements formation, military system. 